\title{
Improvement of Basal Cell Carcinomas in Patients with Nevoid Basal Cell Carcinoma Syndrome Following by 5-Aminolevulinic Acid Photodynamic Therapy: A Case Report
}

Yan Jing Chen iD*

Qin Yi*

Yi Ming Li

Li Li

Department of Dermatology and Venereology, West China Hospital, Sichuan University, Chengdu, Sichuan, People's Republic of China

*These authors contributed equally to this work
Correspondence: $\mathrm{Li} \mathrm{Li}$

Department of Dermatology and Venereology, West China Hospital,

Sichuan University, Guoxue Alley No. 37,

Wuhou District, Chengdu, Sichuan,

6I004I, People's Republic of China

Tel +86 I898060I692

Email lilihx_scu@scu.edu.cn

\begin{abstract}
Nevoid basal cell carcinoma syndrome (NBCCS) is a rare autosomal dominantinherited disease characterized by multiple basal cell carcinomas, multiple keratocystic odontogenic tumors, palmar and/or plantar pits. A 50-year-old male patient presented to our hospital with multiple plaques and maculopapular lesions on his face and trunk for more than 20 years. A skin biopsy revealed a number of discrete nests of basaloid cells in the dermis where the peripheral cells are arrayed like a palisade. Multiple odontogenic keratocysts and falx cerebri calcification were found. The diagnosis of NBCCS was made. We treated this patient with 5-aminolevulinic acid photodynamic therapy (ALA-PDT) with red light activation, $5 \%$ imiquimod cream and surgical excision for the basal cell carcinomas. All the skin lesions on his face improved substantially after eight sessions of red-light ALA-PDT from clinical observation. Red-light ALA-PDT proved to be a good therapeutic method for NBCCS in this case.
\end{abstract}

Keywords: nevoid basal cell carcinoma syndrome, basal cell carcinomas, ALA-PDT, renal cysts

\section{Introduction}

Nevoid basal cell carcinoma syndrome (NBCCS) is a rare autosomal dominant hereditary disease, also known as Gorlin-Goltz syndrome. NBCCS is characterized by multiple basal cell carcinomas (BCCs), odontogenic keratocysts of jaw, palmar and plantar pits, falx cerebri calcification and skeletal abnormalities. ${ }^{1}$ Here, we present an NBCCS patient with rare manifestations of mesenteric and para-aortic nodules, renal cysts as demonstrated by histopathology and imageology. His skin lesions were successfully improved by treatments of red-light 5 -aminolevulinic acid photodynamic therapy (ALA-PDT) with an adjuvant therapy of surgical excision. To our knowledge, only one similar case associated with renal cysts has been reported. $^{2}$ Currently, a few reports have proven that photodynamic therapy (PDT) is effective in producing satisfactory responses in the treatment of NBCCS. ${ }^{3}$

\section{Case Report}

We presented a 50-year-old male patient with multiple plaques and maculopapular lesions on his face and trunk for more than 20 years. Recurrent erosions and ulcers 
intermittently occurred over the plaque in the anterior right tragus in the last 3 years. He denied a history of long-term exposure to sunlight or radiation. The hereditary history was negative. Physical examination revealed absent right-ear lobe, asymmetrical black plaques, maculopapules, atrophic scars with bulged edges and partially ulcerated skin lesions on his face and back (Figure 1A and B). The panoramic radiograph of the oral cavity showed multiple odontogenic keratocysts (Figure 2A). Skull computed tomography (CT) found falx cerebri and tentorium cerebellum calcification
(Figure 2B). Contrast-enhanced CT of the abdomen showed bilateral renal cysts, mesenteric and para-aortic nodules (Figure 2C-F). Chest CT, echocardiography and spine $\mathrm{X}$-ray were unremarkable. Histopathology of three biopsy specimens revealed partial missing epidermis, and a number of discrete nests of basaloid cells in the dermis where the peripheral cells are arrayed like a palisade. Adjacent stromal retractions with empty space formations were also noticed. An amount of mucin surrounding the tumor masses existed (Figure 3A-F). Supported by these findings, we diagnosed

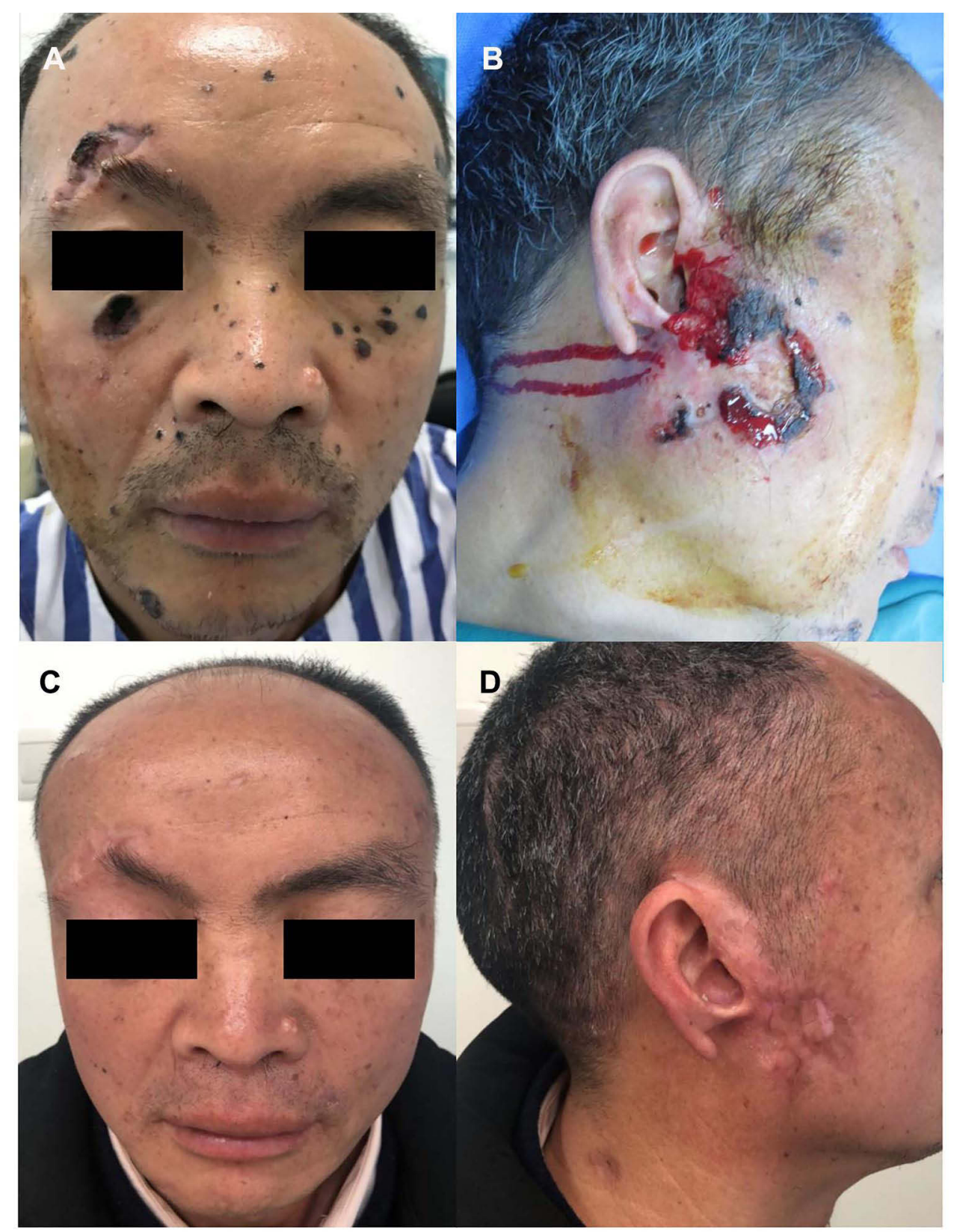

Figure I Main clinical manifestations. (A and B) Multiple plaques, maculopapules, atrophic scars with bulged edges and partial ulcerated skin lesions on his face; (C and D) Facial skin lesions after 8 sessions of 5 -aminolevulinic acid photodynamic therapy. 


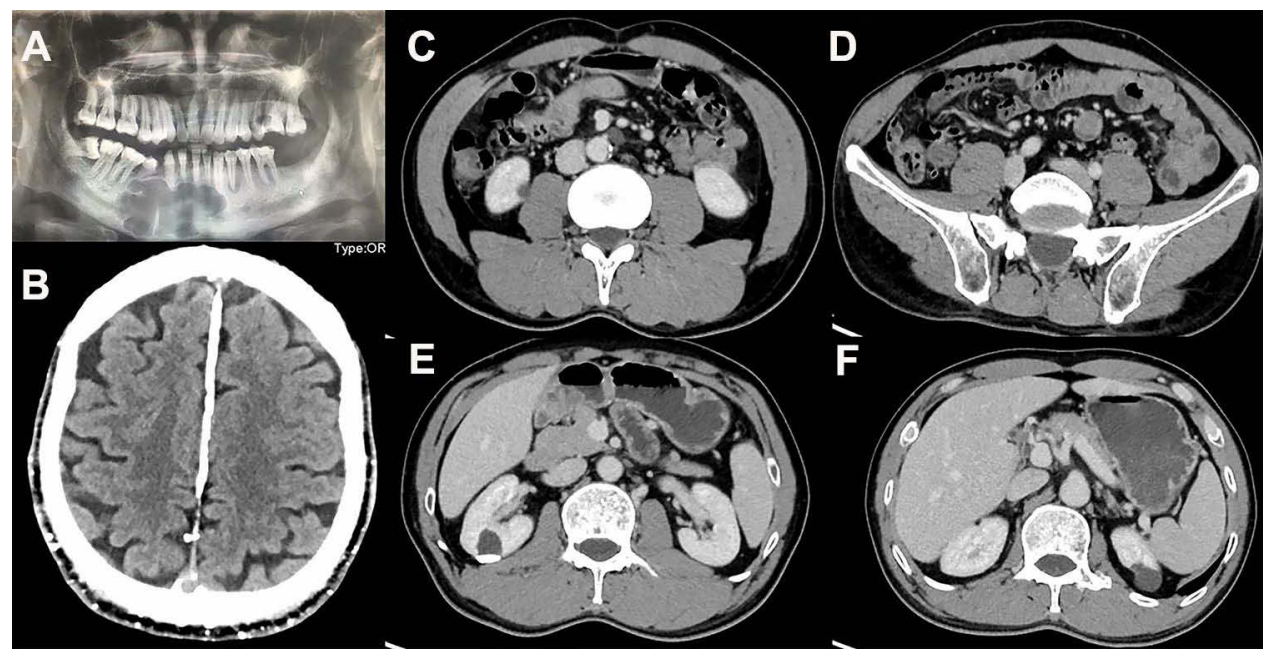

Figure 2 Radiographic findings. (A) Panoramic radiograph of the oral cavity revealed multiple odontogenic keratocysts; (B) Skull computed tomography showed calcification of the falx cerebri; (C-F) Contrast-enhanced computed tomography of the abdomen revealed mesenteric and para-aortic nodules, bilateral renal cysts (the right oneBosniak grade III).

this case with NBCCS. The patient was prescribed a topical ALA-PDT (20\% lotion, Shanghai Fudan Zhangjiang BioPharmaceutical Co. Ltd.; Shanghai, China). Before the application of ALA, the plaques and maculopapules on his face were dealt with pyonex (also known as plum-blossom needle, a traditional Chinese tool, which was made up of five or seven stainless-steel needles for delivering the ALA lotion into the dermis), while the ulcer with crusts was managed with Nd: YAG laser. The lotion was applied to the lesions over his face and covered with plastic wrap for 3 hours. The lesions were then irradiated by a narrow band LED-IB (633 \pm $10 \mathrm{~nm}$ ) (Wuhan Yage Ltd.; Wuhan, China) at $80-100 \mathrm{~mW} /$ $\mathrm{cm}^{2}$ with a light dose of $96-120 \mathrm{~J} / \mathrm{cm}^{2}$. The PDT procedure was administered 7-14 days apart. Surgical excision for one of the dorsal lesions was performed. 5\% imiquimod cream was applied on the non-surgical lesions on his back for at least 2 months (three times per week). Moderate pain was complained during the illumination, and post-therapeutic swelling was also noticed. The ulcer on the right side of the face started to heal after three ALA-PDT sessions. Most of the facial lesions improved substantially after eight ALAPDT sessions within three and a half months (Figure $1 \mathrm{C}$ and D). No obvious change was found on the back (the imiquimod cream treated-area). No recurrence was investigated on his face by the clinical examination in the first three quarters within one year of the follow-up period. However, a relapse with a maculopapule on his nose was noticed and confirmed by histopathology at the end of the follow-up. Due to his personal reasons, he refused to do further examinations, including gene analysis and biopsy of the renal cysts.

\section{Discussion}

The major pathogenic gene of NBCCS is PTCH1 located on q22.3 of chromosome 9 which is more common than PTCH2. ${ }^{4}$ Nearly $70-80 \%$ of patients diagnosed with NBCCS found their parents had the same disease. And the offspring of the patient have a $50 \%$ risk of inheriting NBCCS. $^{5}$

Currently, the recognized diagnostic criteria of NBCCS were proposed by Evans and Kimonis, ${ }^{6,7}$ which recommends meeting two major criteria or one major plus two minor criteria to diagnose NBCCS. Clinically, about $90 \%$ of patients with NBCCS associated with PTCH1 mutations showed multiple odontogenic keratocysts in the jaw. ${ }^{6}$ Therefore, most of the NBCCS patients had their first consultation in the stomatology department for the oral symptoms or routine dental examinations. NBCCS interfere with multiple organs, including the heart, the ovary, the eyes, and bones. The uncommon manifestations are medulloblastoma (5\%) and cardiac fibroma $(3 \%){ }^{6}$ In this case, the patient had bilateral renal cysts, and the right renal cyst was classified as Bosniak grade III, accompanied by the mesenteric and abdominal aortic nodules accidentally. These were unusual even in this rare disease. Renal abnormalities in NBCCS included abnormal kidney morphology, renal cysts, pelvic and ureteral duplication, unilateral renal dysplasia, renal leiomyoma, and nephroblastoma. ${ }^{8,9}$ Most of the patients had no clinical symptoms and were diagnosed by accident via screening for tumor metastasis. Mesenteric changes in NBCCS 


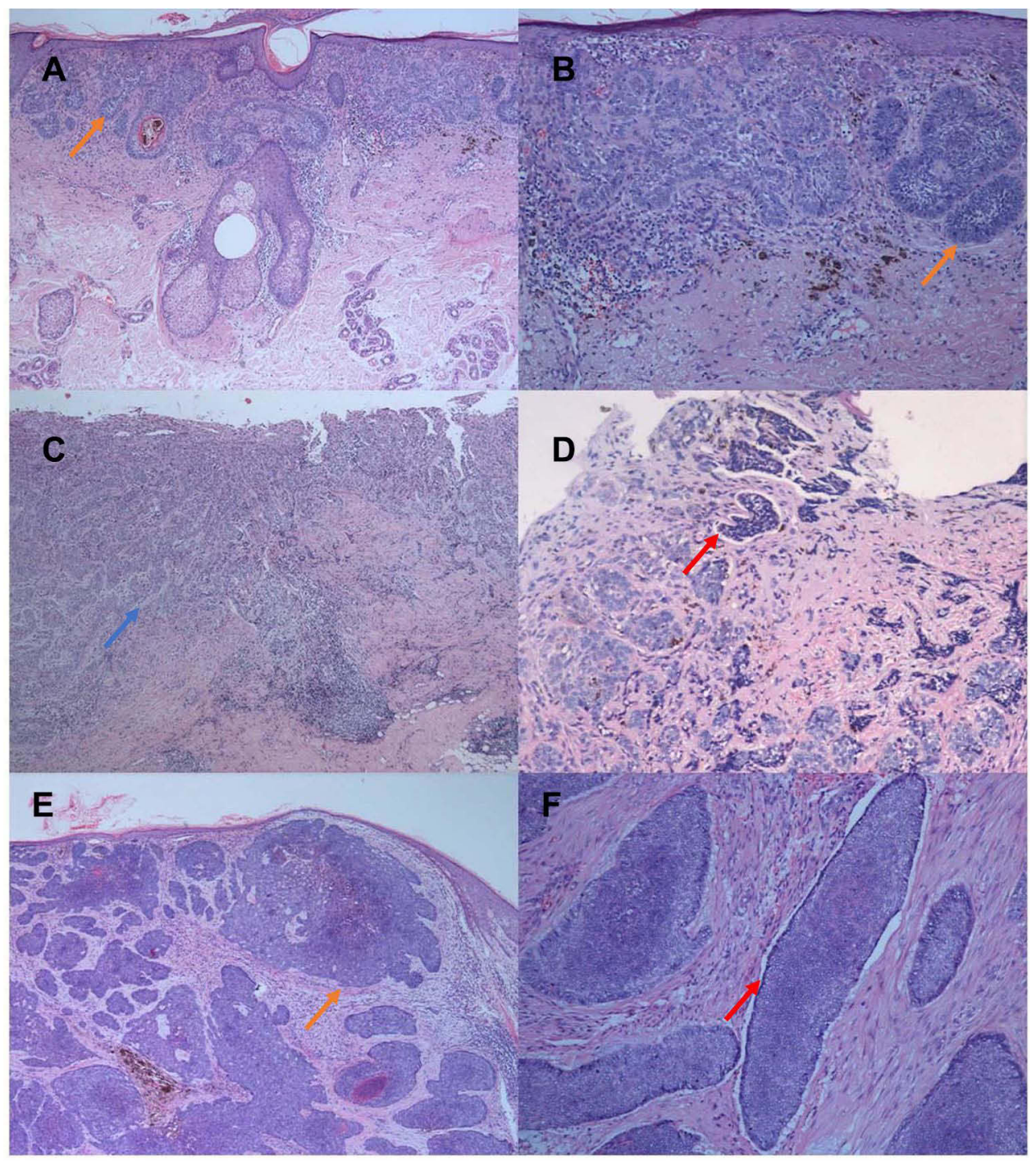

\section{X}

Figure 3 Histopathology of three skin lesions: discrete nests of basaloid cells in the dermis, the peripheral cells are arrayed like a palisade (orange arrows). Adjacent stromal retractions with empty space formations were also noticed (red arrows). Mucin existed among the tumor masses (blue arrow). (hematoxylin eosin, original magnification $\times 40 / 100)$. (A-D) face. $(\mathbf{E}-\mathbf{F})$ back.

patients were rarely reported. In 2016, Rajan firstly reported that mesenteric cysts may be associated with an abnormal Hedgehog signaling pathway. They speculated that mesenteric cysts might be one of the clinical manifestations of NBCCS. ${ }^{10}$ In our case, we suggested further investigations of the patient due to the infeasibility to distinguish the benign or malignant possibility of the cysts through imageology, but he refused.

The treatment of NBCCS is challenging due to multidisciplinary involvements. Monitoring the incidence of tumors and complications associated with NBCCS are mandatory. As for the large numbers of skin lesions, treatment modalities include both surgical and nonsurgical methods. The former option involves surgical excision and Mohs microsurgery. It achieved less recurrence rate than the latter but with worse cosmesis. The non-surgical interventions include cryotherapy, PDT, ultrapulsed $\mathrm{CO}_{2}$ laser, radiotherapy, topical agents (5\% imiquimod or 5- fluorouracil ointment) and oral tablets of retinoids or the hedgehog gene inhibitor (vismodegib). ${ }^{11,12}$ In this case, the patient received red-light ALA-PDT, surgical excision and topical 5\% imiquimod cream simultaneously 


\begin{tabular}{|c|c|c|c|c|c|c|c|c|c|}
\hline 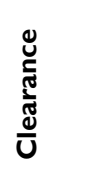 & 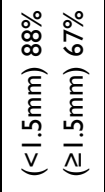 & 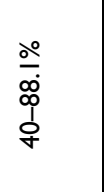 & 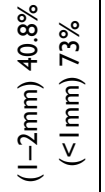 & $\begin{array}{l}\frac{\bar{z}}{3} \\
\frac{0}{5} \\
\text { s. }\end{array}$ & $\begin{array}{l}\stackrel{\circ}{0} \\
\vdots \\
\dot{\omega}\end{array}$ & 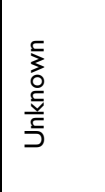 & 离 & 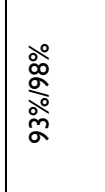 & \begin{tabular}{|l}
$\frac{c}{5}$ \\
o \\
$\frac{5}{5}$ \\
5
\end{tabular} \\
\hline 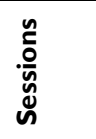 & - & $\sim$ & $\pi$ & $\sim$ & 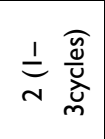 & $\sim$ & $m$ & 0 & - \\
\hline 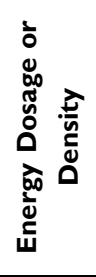 & $\begin{array}{l}\tilde{E} \\
\underline{\underline{\underline{y}}} \\
\underline{\underline{\underline{g}}}\end{array}$ & $\stackrel{\text { EE }}{\stackrel{E}{N}}$ & 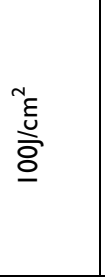 & 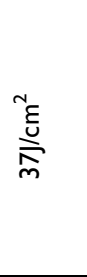 & 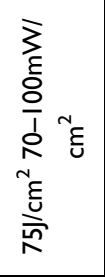 & $\mid \begin{array}{l}\tilde{E} \\
\overline{\overline{\bar{\xi}}} \\
\underline{\bar{\sigma}}\end{array}$ & 竝 & 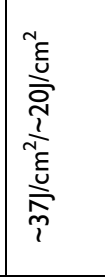 & 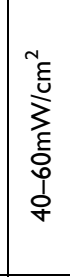 \\
\hline 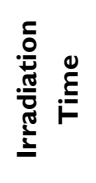 & 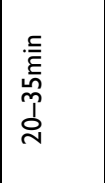 & 宫 & $\begin{array}{l}\frac{\bar{y}}{3} \\
\frac{5}{5} \\
\text { s. }\end{array}$ & 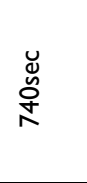 & $\begin{array}{l}\frac{\bar{v}}{3} \\
\frac{0}{5} \\
\frac{v}{5}\end{array}$ & \begin{tabular}{|l|}
$\frac{5}{3}$ \\
$\frac{0}{5}$ \\
$\frac{5}{5}$ \\
\end{tabular} & \begin{tabular}{|l}
$\underline{\bar{E}}$ \\
它
\end{tabular} & 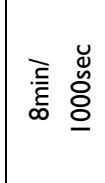 & 喜 \\
\hline 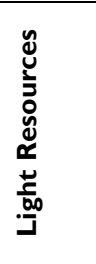 & 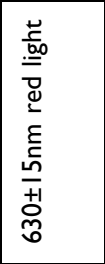 & 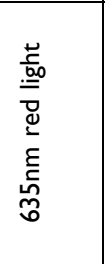 & 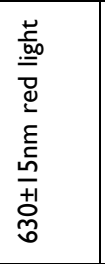 & 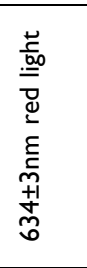 & 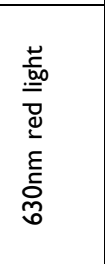 & 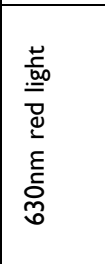 & 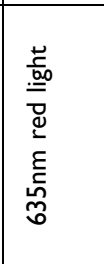 & 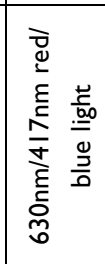 & 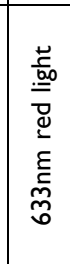 \\
\hline 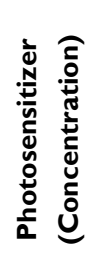 & 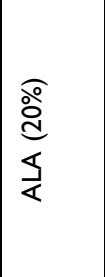 & 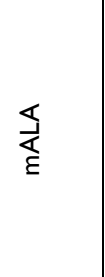 & 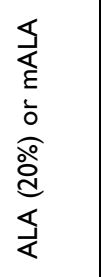 & 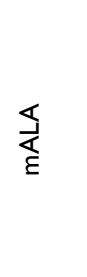 & 崩 & 离 & 䍃 & 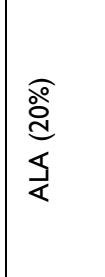 & 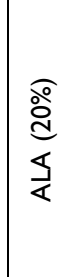 \\
\hline 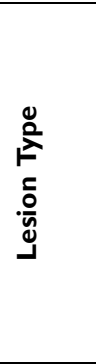 & \begin{tabular}{|l}
$\frac{5}{3}$ \\
0 \\
$\frac{5}{5}$ \\
5 \\
\end{tabular} & 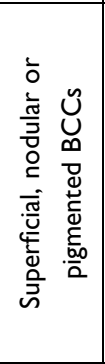 & 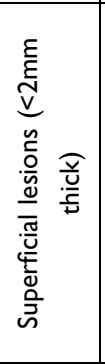 & 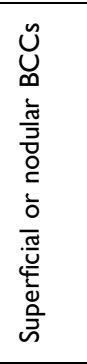 & 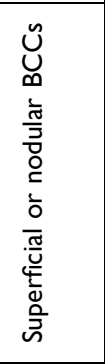 & \begin{tabular}{|l|} 
\\
$\frac{5}{0}$ \\
$\frac{0}{5}$ \\
$\frac{5}{5}$
\end{tabular} & 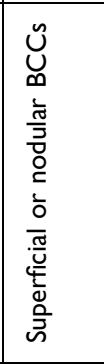 & 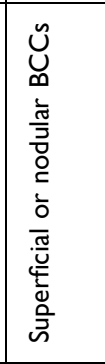 & \begin{tabular}{|l}
$\frac{5}{3}$ \\
0 \\
$\frac{5}{5}$ \\
s.
\end{tabular} \\
\hline 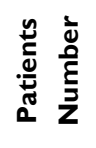 & $\stackrel{\sim}{\sim}$ & in & 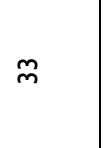 & n & $\sigma$ & - & $n$ & $m$ & - \\
\hline 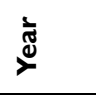 & 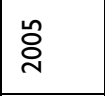 & ذे & ذ્ণ & $\overline{\bar{i}}$ & $\overline{\bar{i}}$ & 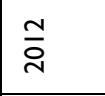 & 商 & $\frac{\infty}{2}$ & 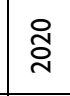 \\
\hline & 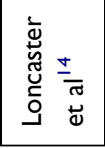 & 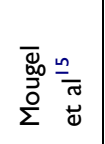 & 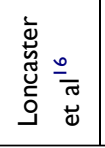 & 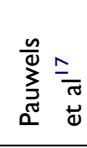 & 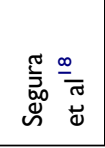 & 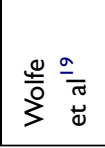 & 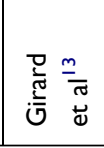 & 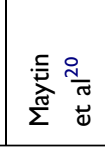 & 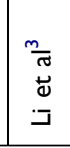 \\
\hline
\end{tabular}


resulting in recovery of partial skin lesions. ALA-PDT was preferred due to the superior cosmetic outcome compared with surgical excision. Previous reports have demonstrated the efficacy of topical PDT for treating BCCs in NBCCS patients (Table 1). The main adverse effects caused by PDT were pain, redness, and swelling. Pruritus, hyperpigmentation and erosion may occur sometimes. Generally, PDT is well tolerated in patients with mild-to-moderate pain during illumination. The pain could resolve within 36 hours. $^{13}$ Although optimal protocols for use of topical ALA-PDT in NBCCS have yet to be determined, PDT should become the first-line therapy for treating multiple BCCs in patients with NBCCS, even for nodular BCCs on the face. ${ }^{13}$

\section{Conclusion}

Nevoid basal cell carcinoma syndrome associated with renal cysts, mesenteric and para-aortic nodules is rarely reported. In this case, utilizing red-light ALA-PDT to treat NBCCS patient's skin lesions proved to be a good therapeutic method. Meanwhile, it is mandatory to cooperate with doctors from different disciplines to diagnose and treat patients with NBCCS.

\section{Ethics Statement}

The publications of images were included in the patient's consent for publication of the case. Institutional approval is not required for this case study.

\section{Patient Consent}

The informed consent of this case report and associated images were obtained from the patient for the publication.

\section{Acknowledgment}

We are grateful to the patient for the permission to use the images and clinical information to be reported in the journal. This work was supported by the $1 \cdot 3 \cdot 5$ project for disciplines of excellence, West China Hospital, Sichuan University.

\section{Disclosure}

The authors report no conflicts of interest in this work.

\section{References}

1. Gorlin RJ. Nevoid basal cell carcinoma syndrome. Dermatol Clin. 1995;13(1):113-125. doi:10.1016/S0733-8635(18)30114-1

2. Santis HR, Nathanson NR, Bauer SB. Nevoid basal cell carcinoma syndrome associated with renal cysts and hypertension. Oral Surg Oral Med Oral Pathol. 1983;55(2):127-132. doi:10.1016/00304220(83)90166-4
3. Li C, Chen P, Li Z, et al. 5-aminolevulinic acid photodynamic therapy and excision surgery for nevoid basal cell carcinoma syndrome with multiple basal cell carcinomas and PTCH1 mutation. Photodiagnosis Photodyn Ther. 2020;32:101968. doi:10.1016/j. pdpdt.2020.101968

4. Hahn H, Wicking C, Zaphiropoulous PG, et al. Mutations of the human homolog of Drosophila patched in the nevoid basal cell carcinoma syndrome. Cell. 1996;85(6):841-851. doi:10.1016/ S0092-8674(00)81268-4

5. Evans DG, Farndon PA. Nevoid basal cell carcinoma syndrome. In: Adam MP, Ardinger HH, Pagon RA, et al., editors. Genereviews $((R))$. Seattle: University of Washington. GeneReviews is a registered trademark of the University of Washington, Seattle. All rights reserved; 1993.

6. Evans DG, Ladusans EJ, Rimmer S, Burnell LD, Thakker N, Farndon PA. Complications of the naevoid basal cell carcinoma syndrome: results of a population based study. J Med Genet. 1993;30(6):460-464. doi:10.1136/jmg.30.6.460

7. Kimonis VE, Goldstein AM, Pastakia B, et al. Clinical manifestations in 105 persons with nevoid basal cell carcinoma syndrome. Am J Med Genet. 1997;69(3):299-308. doi:10.1002/(SICI)1096-8628(19970331) 69:3<299::AID-AJMG16>3.0.CO;2-M

8. Bacanli A, Ciftcioglu MA, Savas B, Alpsoy E. Nevoid basal cell carcinoma syndrome associated with unilateral renal agenesis: acceleration of basal cell carcinomas following radiotherapy. J Eur Acad Dermatol Venereol. 2005;19(4):510-511. doi:10.1111/j.1468-3083.2004.01169.x

9. Garavelli L, Piemontese MR, Cavazza A, et al. Multiple tumor types including leiomyoma and Wilms tumor in a patient with Gorlin syndrome due to 9q22.3 microdeletion encompassing the PTCH1 and FANC-C loci. Am J Med Genet A. 2013;161a(11):2894-2901. doi:10.1002/ajmg.a.36259

10. Rajan N, Brown S, Ward S, et al. Mesenteric cysts in naevoid basal cell carcinoma syndrome: a mimic of metastatic disease. $\mathrm{Br}$ J Dermatol. 2016;174(3):684-685. doi:10.1111/bjd.14224

11. van der Geer S, Ostertag JU, Krekels GA. Treatment of basal cell carcinomas in patients with nevoid basal cell carcinoma syndrome. J Eur Acad Dermatol Venereol. 2009;23(3):308-313. doi:10.1111/ j.1468-3083.2008.03040.x

12. Migden MR, Chang ALS, Dirix L, Stratigos AJ, Lear JT. Emerging trends in the treatment of advanced basal cell carcinoma. Cancer Treat Rev. 2018;64:1-10. doi:10.1016/j.ctrv.2017.12.009

13. Girard C, Debu A, Bessis D, Blatière V, Dereure O, Guillot B. Treatment of Gorlin syndrome (nevoid basal cell carcinoma syndrome) with methylaminolevulinate photodynamic therapy in seven patients, including two children: interest of tumescent anesthesia for pain control in children. J Eur Acad Dermatol Venereol. 2013;27(2): e171-175. doi:10.1111/j.1468-3083.2012.04538.x

14. Loncaster JA, Moore JV, Allan D, Allan E. An ultrasound analysis of the response of Gorlin syndrome-related and sporadic basal cell carcinomas to aminolaevulinic acid photodynamic therapy. Photodiagnosis Photodyn Ther. 2005;2(2):149-155. doi:10.1016/ s1572-1000(05)00064-5

15. Mougel F, Debarbieux S, Ronger-Savlé S, Dalle S, Thomas L. Methylaminolaevulinate photodynamic therapy in patients with multiple basal cell carcinomas in the setting of Gorlin-Goltz syndrome or after radiotherapy. Dermatology. 2009;219(2):138-142. doi:10.1159/ 000228316

16. Loncaster J, Swindell R, Slevin F, Sheridan L, Allan D, Allan E. Efficacy of photodynamic therapy as a treatment for Gorlin syndrome-related basal cell carcinomas. Clin Oncol. 2009;21 (6):502-508. doi:10.1016/j.clon.2009.03.004

17. Pauwels C, Mazereeuw-Hautier J, Basset-Seguin N, et al. Topical methyl aminolevulinate photodynamic therapy for management of basal cell carcinomas in patients with basal cell nevus syndrome improves patient's satisfaction and reduces the need for surgical procedures. J Eur Acad Dermatol Venereol. 2011;25(7):861-864. doi:10.1111/j.1468-3083.2010.03854.x 
18. Segura S, Puig S, Carrera C, Lecha M, Borges V, Malvehy J. Noninvasive management of non-melanoma skin cancer in patients with cancer predisposition genodermatosis: a role for confocal microscopy and photodynamic therapy. J Eur Acad Dermatol Venereol. 2011;25 (7):819-827. doi:10.1111/j.1468-3083.2010.03871.x

19. Wolfe CM, Green WH, Cognetta AB Jr, Hatfield HK. A possible chemopreventive role for photodynamic therapy in Gorlin syndrome: a report of basal cell carcinoma reduction and review of literature. Australas J Dermatol. 2013;54(1):64-68. doi:10.1111/j.1440-0960.2012.00922.x
20. Maytin EV, Kaw U, Ilyas M, Mack JA, Hu B. Blue light versus red light for photodynamic therapy of basal cell carcinoma in patients with Gorlin syndrome: a bilaterally controlled comparison study. Photodiagnosis Photodyn Ther. 2018;22:7-13. doi:10.1016/j. pdpdt.2018.02.009

\section{Publish your work in this journal}

Clinical, Cosmetic and Investigational Dermatology is an international, peer-reviewed, open access, online journal that focuses on the latest clinical and experimental research in all aspects of skin disease and cosmetic interventions. This journal is indexed on CAS.

Submit your manuscript here: https://www.dovepress.com/clinical-cosmetic-and-investigational-dermatology-journal
The manuscript management system is completely online and includes a very quick and fair peer-review system, which is all easy to use. Visit http://www.dovepress.com/testimonials.php to read real quotes from published authors. 